\title{
Law centres and the future of community-based legal services
}

by Steve Hynes

The North West has a relatively high number of law centres, but the overall outlook for legal aid work is gloomy.

\section{THE EARLY YEARS OF THE LAW CENTRES ${ }^{\circledR}$ MOVEMENT}

$\mathrm{T}$ The first law centre was established in North Kensington, London, in 1969 by a solicitor assisted by a trainee solicitor. It offered a free service to its local community and where possible legal aid was claimed for clients. This was quickly followed by the establishment of Brent (in London) and Cardiff Law Centres.

The Law Society was initially hostile to the development of law centres as solicitors in private practice felt threatened by the establishment of a "salaried legal service." An agreement was eventually struck with the Law Society, which allowed the continued existence of law centres on the understanding that they would specialise in areas of work which did not impinge on the commercial interests of private practice. After this agreement Law Centres mainly offered services in welfare rights, immigration, employment, discrimination, housing and public law. These areas of law collectively became known as "social welfare law" and this equates to the internationally more recognised term of "poverty law."

While the type and range of work law centres undertake does vary, they all share the following defining characteristics:

- Independence. Each law centre is incorporated as a company limited by guarantee, owned by its members and run by a management committee drawn primarily from the community that the law centre serves. The majority of members on each management committee are elected. Furthermore, to satisfy the Law Society's Employed Solicitors Code, no funding agent can have majority representation on the management committee, and the law centre must remain independent of central and local government. All law centre staff are accountable to their management committee.

- Legal work. Law centres seek to remedy injustice by a combination of expert legal casework services and strategically directed educational, group and social policy work related to legal issues on behalf of the communities they serve.

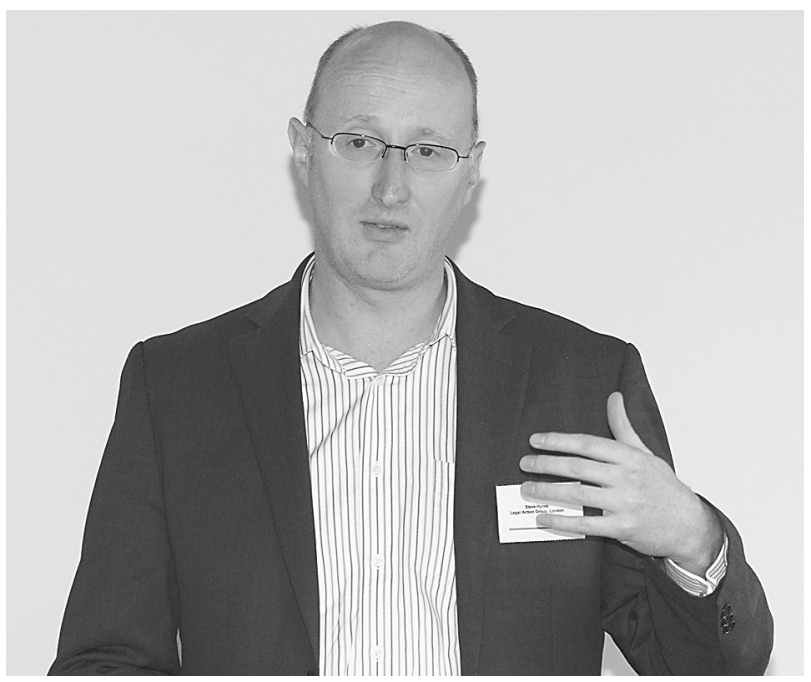

Steve Hynes

- Legally qualified staff. All Law centres employ at least two solicitors, of which one or more has to be a "supervising solicitor" within the meaning of the Law Society's Practice Rules.

- Law Centres Federation (LCF). All Law centres are members of the LCF.

- Publicly funded. Each law centre relies on public money to pay for the services it provides.

\section{GROUND-BREAKING CASES}

Law centres have a well-established reputation for being at the cutting edge of developments in social welfare law. Examples of leading cases include $R_{v}$ Secretary of State for Employment ex p Seymour-Smith and Perez, C-167/97, February 9, 1999 in which Camden Law Centre represented employees who had been unfairly dismissed but were prevented from bringing a case because they had under two years' service. This led to a change in the law on unfair dismissal.

In a 2006 case, Hammersmith and Fulham Law Centre represented clients who had claimed asylum after coming to the UK from Afghanistan. This case gained some notoriety as the refugees had taken the extreme action of 
hijacking a plane to get to this country. The nine Afghan dissidents had been acquitted of hijacking the plane that had brought them to the UK by successfully arguing duress, but the government from the Prime Minister down, fuelled by tabloid outrage, was determined to try and circumvent the law and not grant them asylum by delaying making a decision on their application pending making changes in the law.

This case illustrates that law centres sometimes find themselves defending the rule of law against political interests. The law centre challenged the legality of the government's delaying tactics through a judicial review. Tony Blair said that this successful judicial review was "an abuse of common sense." The then Home Secretary John Reid said: "I continue to believe that those whose actions have undermined any legitimate claim to asylum should not be granted leave to remain in the UK."

The government appealed the decision. In the Court of Appeal judgment (S and others and Secretary of State for the Home Department [2006] EWCA Civ 1157) Lord Justice Brooke said: "We commend the judge [Mr Justice Sullivan] for an impeccable judgment. The history of this case through the criminal courts ... has attracted a degree of opprobrium. Judges and adjudicators have to apply the law as they find it, and not as they might wish it to be."

\section{UNRELIABLE FINANCES}

In the early years, Law Centres did not have reliable finances and were dependent on charitable grants. In 1974, the first grants were made by local government and, the following year, the Lord Chancellor's Department made grants to ensure the future of eight Law Centres. At this point the government was committed to diverting some resources from legal aid to developing a network of Law Centres, but the change of government in 1979 led to a change in this policy (see "LAG's early days: some reflections", Cyril Glasser, October 1997, Legal Action).

The incoming Conservative government took the view that any further expansion of law centres should be funded by local government. This led to some growth in the number of law centres, but from the mid-1980s onwards, local government finance has been strictly controlled by central government. Over the past 20 years, local councils have had to increasingly choose between funding services that they are obliged to by statute and those which they are not, such as law centres. Also, as law centres usually litigate cases in areas in which the councils provide services, for example housing and social care, some local councils have proved hostile to their development. For these reasons, from the mid-1980s onwards, law centres suffered a period of decline, with some centres closing and the number dropping to fewer than 50 .

Much of social welfare law is enforced at tribunals in which representation is not usually funded by legal aid. Research positive result for clients if they are represented - see The effectiveness of representation at tribunals, Hazel Genn and Yvette Genn, 1989 - but to date the government has resisted calls to extend legal aid to tribunals. Law centres, therefore, are mainly dependent on local government to fund this work and, without this clients cannot be offered a full service, though some representation is provided by pro-bono services.

Law centres have always sought to carry out work in legal education, law reform and social policy with the communities they serve. Again, this is work that is mainly dependent on non-statutory funds from local government as the legal aid scheme mainly funds individual cases in a "judicare" system, which many, including the law centres movement, have argued is a systemic failing (see The future of social justice in Britain: a new mission for the Community Legal Service, Jonathan Stein, LSRIC conference, 2004).

\section{LAW CENTRES IN THE NORTH WEST}

The North West Legal Services Commission (formerly the North West Legal Aid Board) played a leading role in piloting the block contracting scheme which brought many not for profit (NfP) organisations, including law centres, into the legal aid system. Due to this, NfP agencies' share of legal aid funding has grown from $£ 11$ million in 2000 to $£ 79.5$ million last year, and 68 per cent per cent of social welfare law legal aid provision is now provided in the NfP sector (figures taken from the LSC Annual report and accounts 2006/07, July 2007).

The change in contracting has led to an expansion in existing law centres and the establishment of some new ones. There were 60 law centres when this paper was originally written but five of them have closed in the last year, mainly through pressures caused by the legal aid reforms. In the North West, the number of law centres is relatively high; London, with 26 , is the only region with more. This is a reflection of generally supportive local councils; stronger traditions, perhaps, of enforcing legal rights; and the regional Legal Services Commission (LSC), which has for many years supported higher numbers of $\mathrm{NfP}$ agencies than average.

There are currently 10 law centres in the region: Carlisle, Oldham, Rochdale, South Manchester, Wythenshawe, Bury, Trafford, North Manchester, Warrington and Vauxhall. With the establishment of the Community Legal Service in 2000, gaps in social welfare law provision were identified in a number of geographical areas. In a joint initiative between the LSC and the LCF, five new law centres were developed. Three of these - Bury, Trafford and Stockport - are in the North West (Stockport has since closed). 


\section{LAW CENTRES AND THE FUTURE OF LEGAL AID}

As an organisation, LCF argues that the replacement of private practice with a NfP judicare system is not a panacea for the failings of the current judicare system, though: "...there needs to be radical transformation of the UK legal aid system so that holistic legal services that seek to tackle social exclusion and poverty through a combination of casework, legal education, social policy and law reform are established on a statutory basis" ("Publicly funded legal work in the UK and Law Centres", Steve Hynes, Management Information Exchange Journal, Fall 2005, Boston, US).

LCF points to the Ontario community legal clinics as an example of a service that provides expert poverty law casework in combination with work on systemic legal issues (see "Law Centres here, legal clinics over there", Steve Hynes, August 2007, Legal Action 6).

The LSC has adopted a policy of reconfiguring services to include work not funded by it through designing joint tenders with local councils for organisations to provide social welfare law services, through Community legal advice centres (CLACs). The first of these has been established in Gateshead and more, up to 75, are set to follow, though there have been delays in getting them established. The issue is examined in "Is there life after CLACs?", Steve Hynes, February 2007, Legal Action 10.

The joint tendering process for social welfare law is in keeping with the wider policy adopted by the LSC after publication of the Carter report on the future of legal aid. In Legal aid: a market-based approach to reform, July 2006, Lord Carter proposed a system of "best value tendering" based on fixed pricing for all legal aid work to control costs. As a transitionary measure the LSC has introduced a system of fixed fees for civil cases in October 2007. After a partially successful judicial review brought by the Law Society, fixed fees for criminal work were introduced in January 2008.

Law centres' main concern regarding fixed fees is that they will lead to a reduction in specialist casework as suppliers are discouraged from taking on complex cases. There is already evidence that solicitors are changing their case mix to include less complex cases in order to make the new contracting arrangements viable (see for example "Cash flow crisis", Jon Robins, Law Society Gazette, October 11, 2007). Law centres also believe that more solicitors' firms will withdraw from legal aid work, putting pressure on them and the other NfP providers.

The Law Society said in The future of publicly funded legal services, February 2003, p 2, that in the previous 10 years, legal aid rates increased by 25.35 per cent while the costs of running a solicitors' practice increased by 67.52 per cent, and this has led to a decline in the number of solicitors wanting to undertake publicly funded work. The LSC also faces the difficulty that, particularly in civil law, publicly funded work often forms a smaller percentage and relatively less profitable part of private firms' work; this can mean it is quite easy for them to give it up (see "From LAB to LSC - Steve Orchard looks back”, LAG, 2003).

To date, though, the number dropping out of civil legal aid work due to the introduction of fixed fees is small. Only 5 per cent of private practice solicitor firms and 3 per cent of NfP agencies gave up legal aid work last April when they had to sign contracts which included provisions for the introduction of fixed fees. These are relatively small numbers as the trend in recent years has been for solicitors undertaking a small percentage of their overall work in legal aid to withdraw and for the remaining firms and NfP agencies to expand.

For their part, the law centres and other NfP providers are distinctly gloomy about the outlook for legal aid work. Morale is at a low ebb. Some suppliers tell the Legal Action Group that they plan gradually to leave the system over the coming months through the use of transitional provisions. With the continuing pressures on local government finance there is unlikely to be large increases in local government funding.

LAG will continue to monitor the coverage and degree of expertise in legal services as fixed fees and tendering are rolled out in the coming years. We will also continue to argue that access to Law Centres and other publicly funded legal services here in the North West and across the country is essential to ensure that everyone, even the poorest in our society, can have equality before the law.

\section{Steve Hynes}

Director of the Legal Action Group (LAG). LAG is a charity, which through its publishing and training services plays an important role in increasing lawyers' and advisers' knowledge of the law. It also carries out policy and campaigning work mainly focused on publicly funded legal services, advocating for the voice of the end user to be heard.

Before joining LAG, Steve was the director of the Law Centres Federation (LCF). LCF is the national organisation for Law Centres and it provides representation and support to the network of 60 Law Centres in England, Wales and Northern Ireland. Over the years, Law Centres have played a prominent role in providing legal services to disadvantaged communities. 